\title{
Chapter 10 \\ The Fight Against Corruption in Brazil: A Case of Good Governance?
}

\author{
Markus Pohlmann and Elizangela Valarini
}

Since the start of Operation Carwash (Operação Lava Jato) ${ }^{1}$ in March 2014, politics, senior executives, and the judiciary have been in great turmoil in Brazil. Having ensnared the construction industry and Petrobras, the state-run oil company, the specter of corruption is now threatening to envelop other state-owned enterprises, such as the nuclear energy industry, with the construction of nuclear power plants as well as further Brazilian federal entities, such as the Brazilian Development Bank (BNDES), a Brazilian federal bank, the Caixa Econômica Federal, etc. Operation Carwash became the largest ever ongoing criminal investigation in Brazilian history. In special, the criminal process against the former President Luiz Inácio Lula da Silva and his political party, the Workers' party (Partido dos Trabalhadores (PT)), detonated a political tinderbox. Not only have the accusations against ex-President Lula, the impeachment against his successor Dilma Roussef, the arrest of the President of the Parliament, Eduardo Cunha of the Brazilian Democratic Movement Party (Partido do Movimento Democrático Brasileiro (PMDB)), and current proceedings against roughly 279 politicians robbed the Brazilians of their sleep, the sheer multitude of corruption scandals in the economy also keeps them in suspense.

What is going on in Brazil? And what is behind these scandals? It seems that tolerance of corruption in Brazil reached a turning point. Whereas criminal processes and sentences were once slight and rare, and only pronounced with the exclusion of the general public, they are now coming fast, hitting hard, and reaching the

\footnotetext{
${ }^{1}$ The name Operation Carwash have been giving from Brazilian Federal Police to the uncovered scheme of money laundering that was linked to a chain of gas stations and car wash systems. Later, the data showed that this case was linked to the Petrobras corruptions scheme.
}

M. Pohlmann $(\bowtie) \cdot$ E. Valarini

Max-Weber-Institute of Sociology, Heidelberg University, Heidelberg, Germany

e-mail: markus.pohlmann@ soziologie.uni-heidelberg.de;

elizangela.valarini@mwi.uni-heidelberg.de

J. Glückler et al. (eds.), Knowledge for Governance, Knowledge and Space 15,

https://doi.org/10.1007/978-3-030-47150-7_10 
news. With the enacting of the Freedom of Information Act no. 12.527/2011, ${ }^{2}$ anyone who is curious enough can easily follow the trials on official sites of the justice system, but also in the media. Also, punishment became harsher. For example, the federal court of Paraná sentenced Marcello Odebrecht, the president of one of the biggest business groups in Brazil, and a descendant of a German immigrant family, to 19.4 years on the charges of bribery, participating in organized crime, and money laundering.

In our article, we will investigate the unlawful practices of the Brazilian construction companies involved in the Petrobras plot and their relationship with the public sector. In our analysis of criminal trials, inquiries, testimonials, and examination of the Brazilian context, we attempt to demonstrate that good governance is related to the interaction of various types of institutions (cognitive, normative, and regulative), as well as embedded belief patterns shared in a society. For this purpose, we analyze the institutionalized patterns in a deviant environment and the competitive pressure in which enterprises are embedded. Furthermore, we examine internal organizational incentives and the profits from illegal practices, the hierarchical pressure, as well as the legitimation of unlawful activities, rationalization, and socialization in Brazilian organizations.

Relying on a multilevel analytical approach, we begin our analysis by describing the current Petrobras scandal and the main actors involved. Furthermore, we run our observations on the institutional level, and we analyze the change of regulations, laws, and the efforts of law enforcement agencies to investigate and prosecute corruption in Brazil. We aim to find out what kind of institutional and regulative changes were realized in Brazil and how the switch from defective to more effective regulations took place. In the next chapter, we argue that the defective regulation in the fight against corruption was one significant background and reason for the "normalization of corruption" on a corporate level. Dealing with the actors in charge of running the companies, we analyze how subcultures or social "cocoons" emerged inside the companies, providing frames of action for organizational wrongdoing. We ask whether and how so many high-ranking officials and senior managers took part in the corrupt setup. One of the stunning facts revealed by Operation Carwash's investigators is how closely cartel building and bribe paying by important members of Brazil's big business was intertwined with illegal party financing and political corruption. We thus dedicate the sixth chapter to the analysis of political corruption in Brazil as the other side of the coin. Moving back to the actor level, we then ask how many and what kind of political actors have been involved and which

\footnotetext{
${ }^{2}$ According to the Freedom of Information Act, enacted in November 2011, all public agencies, members of the direct administration of the Executive, Legislative, including the Audit Courts and Judiciary and Public Prosecution as well as all municipalities, public foundations, state-owned enterprises, mixed-capital-companies and other entities directly or indirectly controlled by the Federal Government, States, Federal District and Municipalities must to divulge all information related to their administration, such as income and expenses as well as produced and guarded information that are of collective interest (http://www.planalto.gov.br/ccivil_03/_ ato2011-2014/2011/lei/112527.htm).
} 
framework of political wrongdoing has been established. Could Operation Carwash destroy the pattern of political corruption? In our subsequent conclusions, we will address whether the Brazilian case is just one of effective changes in law enforcement or a case of "good governance" as well.

\section{The Brazilian Petrobras Plot}

The Petrobras plot unveiled a complex and profound corruption scheme in Brazil. The number of political parties, enterprises, high-ranking politicians, executives, and managers as well as the sophisticated modus operandi discovered in the context of Operation Carwash was unprecedented in Brazilian society. The case's magnitude, but also the change in the methods and procedures applied on Operation Carwash, makes it a crucial case for social scientists.

Since Operation Carwash was launched in March 2014, its investigators have discovered US $\$ 2$ billion of bribery payments from private companies to Petrobras senior executives, politicians, and political parties. More than 760 cases are now in court, involving politicians, senior executives, owners of Brazil's largest enterprises, and other actors. 182 people have been convicted, penalties add up to 1809 years. ${ }^{3}$

To understand the Petrobras case, we shall pay attention to four core investigated groups. The first core group consists of senior executives occupying key positions at three of Petrobras's business units: Supply, International, and Corporate and Services. Petrobras's executive directors, supported by political parties, ensured access to the expensive Petrobras contracts for a distinct group of Brazilian private construction companies. In return, the construction companies paid them somewhere between $1 \%$ and $3 \%$ on top of the contract's value. In this context, it is also important to account for the composition of the executive boards at Brazilian stateowned enterprises. Generally, the directors are appointed by government officials, the President, and/or members of the political parties. In the case of Petrobras, the directors of the executive board were supported by political parties of the current ruling coalition: PT, PMDB, and PP (Progressive Party/Partido Progressista). The second main group in the Petrobras case was the so-called black market dealers. These intermediaries served as a link between Petrobras executives and managers of the construction companies, as well as between the government and party members. Furthermore, they were responsible for finding means to launder the money from bribery payments. The third group involved in this bribery scheme consists of the largest Brazilian construction companies. They were organized in a cartel to obtain Petrobras's major public bids related to their business areas and allocate the contracts internally. The cartel dealt with Petrobras directors and makes it possible to restrict and exclude new bidders interested in Petrobras projects. Thanks to their "agreement" with Petrobras' senior managers, they ensured that the bid winner

\footnotetext{
${ }^{3}$ See http://www.mpf.mp.br/grandes-casos/lava-jato (accessed 23.02.2018).
} 
always came from within the cartel. The fourth main group of suspects uncovered by Operation Carwash investigators is made up of politicians, government officials, and political parties, in other words: the bribe takers. ${ }^{4}$ Leaders of political parties, politicians, such as state and federal deputies, senators, and ministers financed their political parties, campaigns, and political alliances through payment of bribes. Even the former republic President Michel Temer is suspected of receiving bribes from large enterprises, ${ }^{5}$ as was the former President Luiz Inacio Lula da Silva, who was sentenced to 12 years in prison. ${ }^{6}$

According to Petrobras's internal audit (Petrobras, 2014), perpetrators violated a series of the company's internal rules and general laws about public bids. ${ }^{7}$ The government has regulated public bids for hiring a service provider through strong legislation: Lei No. 8.666/1993. For the success of the bribery scheme, the participation of the business unit "Corporate and Services" was strategic, because its members were in charge of the bid procedures and regulations, project price calculation, as well as selection and accreditation of partner companies. The board of Corporate and Service alone could not approve new contracts, because the bid process demanded several business units, departments, and the monitoring of board members, but according to the former Petrobras president between 2012 and 2015, Maria das Graças Foster, ${ }^{8}$ the expertise and professional competence of the director of this unit was appreciated. In this respect, the business units' directors had a large scope to influence or even "manipulate" the results of bid proceedings in favor of their interests.

\footnotetext{
${ }^{4}$ See trials for administrative improbity: 500662892.2015.4.04.7000/PR; 5006717-18.2015.4.04.7000/PR; 5006695-57.2015.4.04.7000/PR; 5006675-66.2015.4.04.7000/ PR; 5011119-11.2016.4.04.7000/PR; 5006694-72.2015.4.04.7000/PR; and criminal trials: 5083351-89.2014.4.04.7000/PR; 504524184.2015.4.04.7000/PR; 508325829.2014.4.04.7000/ PR;5083401-18.2014.4.04.7000/PR;5083376-05.2014.4.04.7000/PR;503652823.2015.4.04.7000/ PR;508336051.2014.4.04.7-000/PR;501233104.2015.4.04.7000/PR;507344138.2014.4.04.7000/ PR; 5027422-37.2015.4.04.7000/PR; 502698037.20-16.4.04.7000/PR).

${ }_{5}^{5}$ Inquiry number 4.483/DF, documents 162339/2017/GTLJ-PGR and 162973/2017/GTLJ-PGR. ${ }^{6}$ Criminal trial 5046512-94.2016.4.04.7000/PR. The sentence and result of the appeal court decision has not yet been issued.

${ }^{7}$ Public bid is the set of laws to regulate the contracts between public and private sector, but also is used to administer contracts for purchasing materials and supplies by public entities. The public bid law aims to ensure that public entities receive the best possible price for the supplies or public works.
}

${ }^{8}$ Maria das Graças Foster's testimony https://www.youtube.com/watch?v=9TkDOJZlLOg 


\section{Institutional and Regulative Changes in Brazil: From Defective to Effective Institutions and Regulations?}

On the institutional level, we are analyzing the changes in legislations and law enforcement over the last two decades, concerning political and economic corruption in Brazil. We are focusing mainly on the constitutional reality and the policy outcome, that is, on the efficiency and effectiveness of law enforcement in Brazil. Not long ago, there was a lack of law enforcement and monitoring systems for private and public corruption (Chaves, 2013), creating an institutional environment prone to deviance and corruption. For example, Brazilian legislation does not yet cover private corruption ${ }^{9}$ (Pascolati Junior, 2016), some politicians have legal immunity, and thus, under the constitution, due this legal status they can be just investigated and prosecuted in special courts, such as the supreme court. According to the Carwash' prosecutors, although the penalties for corporate crime and political corruption have become more severe, the probability of being detected and incarcerated remained low (Dallagnol, 2017). What we call "defective institutions and defective regulations" have been part of the Brazilian reality concerning the fight against corruption.

In our discussion, we differentiate between institutions and regulations. We define institutions as cognitive, normative, and regulative structures and/or activities that run on stability, but also constrain, regularize, and give meaning to social behavior, but assume an impersonal and objective form of reality (Scott, 2014). They incorporate both symbolic systems and regulative processes that orient social action and organizational behaviors in a defined social group and/or society (Bathelt \& Glückler, 2014; Scott, 2014). Furthermore, institutions are determined by locality, cultural patterns, social conditions, etc., and constituted and reproduce by ongoing social interaction existing in a specific social context (Glückler, Suddaby, \& Lenz, 2018). "Although institutions may represent the intentions inherent in rules" (Bathelt \& Glückler, 2014, p. 356), they differ from rules, laws and regulations. These can regulate social interaction from organizations and actors independently if those behind social beliefs or a common knowledge. In that sense, rules, laws and regulations can regulate social practice through their sanction systems (Bathelt \& Glückler, 2014). Thus, introduced laws, rules and regulations can lead to different outcomes, depending the existing institutions, with them the new regulation will be interact (Glückler \& Lenz, 2016).

Institutions and regulations are defective when laws and directives, such as anticorruption laws, do exist but these either fail to set sufficient standards or the administrative enforcement thereof is patchy or inadequately guaranteed. In this case, the constitutional legal bases are not undermined, but the purpose of the regulation is largely missed. The fight against corruption may be only "nice to have," as one has

\footnotetext{
${ }^{9}$ Bill 236/2012 has been in process since 2012 in the Brazilian Federal Senate to implement the penal legislation with legal instrument to define and punish private corruption (Pascolati Junior, 2016, p. 148).
} 
repeatedly witnessed over the past years. We believe that such a defective regulation creates important preconditions for the emergence of forms of deviant self-regulation at the level of enterprises. And that is exactly what happened in the case of the fight against corruption in Brazil. Defective regulations and institutions are, in this sense, functional for the maintenance of a system that systematically and legally subverts the purposes of statutory regulation. We call this "systemic corruption."

In the 1990s, the global diffusion of regulatory agencies (Braithwaite, 2008; de Rugy \& Warren, 2009; Jordana, Levi-Faur, \& Fernández i Marín, 2011) also spread to Brazil, a country which a long-lasting tradition of a regulatory state and regulatory capitalism (Braithwaite, 2008). Although impeded by a self-sustaining pattern of cronyism, a new phase of regulation emerged in Brazil as well, leading to the detection and prosecution of big corruption scandals. In the last decades, Brazil has committed itself, through several international agreements, ${ }^{10}$ to fighting against corruption (Barkemeyer, Preuss, \& Lee, 2015; Dantas de Araujo, 2012; de Sanctis, 2015; Richard, 2014). To do so, Brazil has implemented a national strategy against corruption, organized crime, and money laundering, the National Strategy for Combating Corruption and Money Laundering (Estratégia Nacional contra a Corrupção e a Lavagem de Dinheiro (ENCCLA)) (de Sanctis, 2015). This initiative is not only a new paradigm to combat corruption and economic and financial crimes, but it is also responsible for concrete changes aimed at involving the judicial system more strongly in the execution and investigation of corruption cases. The new Anti-Corruption Act n. 12.846/2013 is a result of the support of the ENCCLA's strategies. Its significant change consists in the accountability and punishment of Brazilian and foreign companies as legal entities. They can be addressed by the penal code and have obligations to install compliance systems (Chaves, 2013; Correia, 2015; Wohlnick \& Correia, 2016).

The diffusion of international anticorruption policies in Brazil has fomented a series of changes related to new regulation, such as enacting of laws and rules to regulate and control the public administration and to generate more transparency of public spending and public activities (Lei No. 8.112/1990; Lei No. 8.429/1992; Lei Complementar No. 101/2000; Lei Complementar No. 131/2009; Lei No. 12.527/2011), the business relation between the public and private sector (Lei No. 8.666/1993; Lei No. 10.520/2002), and so forth. (Filgueiras \& Araújo, 2014). Some authors have also pointed to changes related to the perception of Brazilian society about corruption. With the redemocratization process, the corruption scandals have also become public. Most recent changes on the institutional level in Brazil related to laws and regulations, such as the Anti-Corruption Act, may be the product of civil society pressure (Filgueiras \& Araújo, 2014). Even if the perception about corruption in Brazilian society over time seems to be changing, small and large corruption is still affecting the relation between actors, organizations, and government.

\footnotetext{
${ }^{10}$ United Nations Convention against Transnational Organized Crime; Convention on Combating Bribery of Foreign Public Offices in International Business Transactions (OECD); Convention on Combating Bribery (UK) (2003); United Nations Convention against Corruption (Mérida Convencion); Inter-American Convention against Corruption; and so forth.
} 
The regulative changes have been impressive and well acknowledged all over the world as good governance in the fight against corruption. Yet it is more precise to call it "good law enforcement" and to keep open whether it leads to a mode of good governance, in which various interest groups and societal actors engage in the fight against corruption.

\section{The "Normalization of Corruption" on a Corporate Level}

In our view, defective regulations in the fight against corruption are one important precondition for the "normalization of corruption" on a corporate level. By analyzing the cartel of construction companies, we discovered that only $30 \%$ of these enterprises had a code of conduct to regulate the business relations in- and outside of the company before Operation Carwash began. Our analysis revealed that although these enterprises do have a code of conduct, the terms and clauses prescribing rules of doing business ethically and those declaring illegal and unlawful behavior to be punishable are phrased vaguely. Furthermore, in the code of conduct was lacking a precise description of no acceptable practices and behaviors inside of the organization, in its relationship with the political field and with other enterprises as well as a concretely description of sanctions and penalties against the wrongdoers was missing. Thus, in the code of conduct, this is considered a first step to establishing a compliance system. Most of the companies under investigation by the Operation Carwash had no compliance measures installed. They only started to establish a compliance system when they moved into the spotlight of law enforcement. Only those companies with major business activities abroad or with international investors ran an internal compliance system. However, lawyers and compliance professionals have strongly challenged the legitimacy and effectiveness of the internal compliance (Pizarro, 2015). If we extend our analysis beyond Brazil to the Latin America context, we verify that the introduction of compliance systems to regulate corporate behaviors are a relatively young practice in Latin American countries. According to Passas and Kleinhempel (2016), although 35\% of the existing compliance systems were introduced between 2005 and 2010, more than 50\% were implemented in the last few years. These authors have pointed out that there is a gap in employee awareness about the importance of such programs. An average of $19 \%$ of employees did not know about the introduction of a compliance program in their company (p. 82).

Far more important is that companies like Odebrecht ran departments dedicated to carrying out illicit activities, such as the department Odebrecht called "departamento de operações estruturadas" (department for structured operations) which had existed for decades. According to the former senior manager Hilberto Mascarenhas, the chief officer of Odebrecht's "departamento de operações estruturadas," the company had also established an internal bonus system that provided incentives for paying bribes. In his case, the annual bonus was as high as one third of his annual salary of US\$1.2 million and was part of a provision system for bribe payers. 


\begin{abstract}
What was agreed was this: I will pay you a bonus on the basis of your outcomes. And we will negotiate it annually. So, you may do anything that you need to achieve it [bonus]. So if you ask someone who wants to increase the revenue of his project, but this requires the approval of an 'aditivo' [additional investments] that is still on the table of someone who does not want to approve of it, this person may do everything for the approval of his 'aditivo' to increase the value of his project. (Hilberto Mascarenhas, Odebrecht former senior manager, 2017 testimony ${ }^{11}$ )
\end{abstract}

Moreover, the paid bribes were subtracted from individual bonuses gained through the project, so that the responsible manager had autonomy to fix the sum of the bribe. The existence of a permissive code of conduct and the lack of a working compliance system that may prevent the unlawful activities inside of the organization, therefore, were both elements that gave rise to internal incentives for resorting to illegal practices; both contributed to the establishment of an organizational culture in which such practices were accepted and normalized. In their testimonies, the executives displayed a self-image as professionals that achieved sound performances. In other words, "they did their job."

Of course, by now all these companies have changed their policies concerning the illicit dimensions of their business activities. The "departamentos de operações estruturadas" have been wound up, and the bonus systems terminated. The company Odebrecht repented by running apologies in the print media for its wrongdoing. ${ }^{12}$

\title{
The Corporate Level Actors: Entrepreneurs and Top Managers
}

The number of entrepreneurs, managers, chief executives, and middle managers involved in Operation Carwash increased with every new discovery in the investigation. We concentrated our analysis only on the construction companies, which were accused and convicted of crimes related to cartel formation and their illegal access to the Petrobras contracts. To date, prosecutors have opened eleven criminal trials against sixteen construction companies and 64 executives at the Federal Court of Paraná, ${ }^{13}$ investigating crimes against the state-controlled company Petrobras. Just five of these criminal trials were concluded; the other six are still under investigation. Presently, 33 executives and owners have been convicted of corruption, cartel building, and money laundering, and only nine managers have been absolved, due to lack

\footnotetext{
${ }^{11} \mathrm{https} / / / \mathrm{g} 1$.globo.com/politica/operacao-lava-jato/noticia/executivos-da-odebrecht-superfaturavam-obras-para-ganhar-bonus-da-empresa.ghtml

${ }^{12} \mathrm{See}$ : https://economia.estadao.com.br/noticias/geral,odebrecht-fecha-acordo-de-r-6-8-bilhoes-epede-desculpas-ao-pais-por-pratica-de-corrupcao,10,000,091,979.

${ }^{13}$ The eleven criminal trials against executives, owners, and managers of the construction companies that participated in the price-fixing cartel: 5036528-23.2015.404.7000; 5036518-76.2015.4.04.7000; 5027422-37.2015.4.04.7000; 5025847-91.2015.4.04.7000; 5083351-89.2014.404.7000; $\quad 5083376-05.2014 .404 .7000 ; \quad 5083360-51.2014 .404 .7000$; 5083401-18.2014.404.7000; 5083258-29.2014.404.7000; 5011926-65.2015.4.04.7000.
} 
of evidence. On average, the convicted executives were sentenced to 15 years in prison on top of substantial fines. ${ }^{14}$

The results of the fight against corruption show that the case involves not just a few people, but a large number of entrepreneurs and chief executives in top positions of the construction companies. Both the rank and number of those who perpetuated price-fixing, money laundering, and bribery indicate the institutionalization of a strong subculture or a social cocoon. In the cartel case, the establishment of a deviant subculture can be self-sustaining. For decades the companies have developed a common modus operandi with the public sector: They decide which projects to pursue and at what price to run them, but they also decide, on the basis of the sum of their campaign donation, if their business activities can be perpetuated.

The analysis of court documents, especially the testimonies, not only provided strong evidences for the development of a social cocoon, as well as a subculture inside the organizations, but also gave us an insider's look at the cartel and the relationship among these companies. The social cocoon can be considered as part of the organizational culture, because it thrives and shapes the managers' and employees' values, norms, and attitudes in support of the corrupt practices. The social cocoon differentiates itself from a negative social perspective about corruption, which group members consider as common practices that are necessary for the organization to achieve its objectives (Campbell \& Göritz, 2014). This subculture within the organization is developed over time through three main mechanisms: institutionalization of systematically used corrupt practices; rationalization by plausible social justification for the use of these practices; and socialization of the unwritten rules and informal interpretations within the organization.

Operation Carwash investigators have revealed that the cartel's activities were supported by the top management at the enterprises involved. The senior executives and managers who sustained these practices were on average 69 years old and had worked at the company for 23 years. Thus, socialization and insider recruitment became important factors in establishing and perpetuating the subculture. Moreover, the ways in which illegal practices were normalized, so that the actors involved did not question them, supply strong evidence for the establishment of a social cocoon. The majority of actors questioned during the investigation avoided the official definition of their practices - such as bribery, fraud, and price-fixing - and preferred to use words such as "commission" or "toll" to explain how, when, and why they decided to act corruptly.

Another important element in understanding the corrupt action from the organizational culture's perspective is the benefits for the organization. According to available court documents, the managers and entrepreneurs participating in the Petrobras plot were aiming primarily at the success of the organization. In one case, a senior executive at a construction company explained that the paid bribes may cause disadvantages in the final project costs and consequently this would decrease his

\footnotetext{
${ }^{14}$ Not included here are the 77 executives of Odebrecht who entered into plea bargains.
} 
bonus. ${ }^{15}$ This case is of course not common, but at the same time it is not common either among the cartel companies to identify personal gains as the rule of the game. More than $80 \%$ of the construction companies' implicated senior executives and managers were paying bribes to the Petrobras senior executives, because that was the rule of the game. The unwritten rules were widely known in the construction industry, rather than limited to the entities that participated in the cartel.

Achieving organizational goals may also satisfy personal interest. The highranking managers may get promoted to higher positions, thus ensuring better status and better remuneration. Bonuses and careers play an important role in this case, not just on a personal but also on an organizational level, which awards loyal managers who are pulling the company to a better market position.

Illegal practices related to personal gains are not mentioned in the court documents, because these crimes are not charged in the indictment. But in the course of the investigation investigators also revealed that some managers and senior managers of the investigated enterprises indulged in private deviations. In this case, the managers kept a part of the bribes that were to be delivered to a "black market dealer" or to a politician. Sometimes, they received offers from politicians and other public agents to "help" [pay bribes] in the political campaigns and in retour; they may receive a percentage of the sum. Other executives also misappropriated part of bribes that should be payed to politicians. The number of executives who have owned up to these practices is very low.

These managers' individual deviations were in part supported by the organization, because the bonus system could be understood here as a strong incentive for paying bribes. Even if they pursued personal gains, these actors were still conforming to the informal rules of the organization. Thus, the individual deviance, which is driven by the organization, is an individual expression of collective practices.

But Operation Carwash has changed this landscape. At present, investigators have discovered bribery payments of US $\$ 2$ billion. One-hundred-and-eighteen suspects have been arrested, and fifteen top managers and entrepreneurs were given an average sentence of 15 years. A total of 77 criminal prosecutions against 289 individuals, as well as eight corruption charges against sixteen major construction companies and 50 individuals, are being processed. These accusations are directed against the top management of the largest private construction companies and the state-owned oil company Petrobras. Their presidents, managers, and employees face charges of corruption (article 33, penal code, § 4), money laundering with document forgery (article 1, caput, inciso V, Lei No. 9.613/1998), and the participation in a criminal organization (article 2, Lei No. 12.850/2013).

\footnotetext{
${ }^{15}$ Executive sentenced in the criminal procedure no. 5036518-76.2015.4.04.7000.
} 


\section{The Normalization of Political Corruption}

Teori Zavascki, one of the eleven Ministers of the Supreme Federal Court of Brazil, died on January 19th, 2017, in an aircraft crash. Teori Zavascki was the justice presiding over the trials resulting from Operation Carwash. He was in charge of the legal proceedings of the Petrobras scandal and the intertwining relations between economic and political corruptions in Brazil it helped to unearth. His successor, Luiz Edson Fachin, has assumed the mantle.

One of the first testimonies under the framework of the "Leniency Agreement" with Odebrecht came from Claudio Melo Filho, ${ }^{16}$ a senior manager at the construction's groups department for "institutional relations." His testimonies-whatever judicial value they may turn out to have-suggest that in Brazil, the relations between big companies and politicians who hold the lever of state power go far beyond bestowing simple favors and minor legal backings. According to Melo Filho, Odebrecht and other companies were able to ensure that certain laws were bended in their favor. Melo Filho argues that, as part of this Brazilian favoritism in politics and legislation, companies such Odebrecht returned favors from influential politicians, candidates, and parties in their clique by serving their political interests and fulfilling personal wishes. Claudio Melo Filho described how, over a 12-year period, his company managed to build a network of inroads to cover many highranking politicians.

Melo Filho listed payments by the Odebrecht construction group to various politicians who are now the subject of many investigations and legal proceedings. According to his testimonies, these payments, to the tune of millions of US dollars, were supposed to change certain laws in favor of Odebrecht and other companies. This included, for example, a modification to the legislation on tax preferential treatment of corporate profits of Brazilian companies operating abroad (MP $627 / 13^{17}$ ). Claudio Melo Filho also mentioned nine other legislative reforms and legislative proposals that have been influenced by political donations and payment of bribes over the last decade.

These testimonies against political corruption in Brazil, among others, make it clear that all major political parties have systematically used this method of funding politicians and parties. According to the current investigation, 51\% of the accused and convicted come from the Partido Progressista (PP) party, 22\% from the PMDB party, $18 \%$ from the PT party, around 3\% from the Partido da Social Democracia Brasileira (PSDB), and 6\% from other parties. Admittedly, these results are now changing on a daily basis ${ }^{18}$ (Netto, 2016). It is now known that Odebrecht

\footnotetext{
${ }^{16}$ Inquiry document of Odebrecht's Leniency Agreement: Anexo pessoal from Claudio Melo Filho.

${ }^{17}$ The provisional measure (MP 672/13) was enacted in 2014 and converted into the law 12.973/2014. It regulated the tax payment of Brazilian enterprises that operate abroad (see: http:// www.planalto.gov.br/ccivil_03/_ato2011-2014/2014/Lei/L12973.htm)

${ }^{18}$ The number of involved politicians per political party changes daily according to the investigation.
} 
construction group handed out approximately US\$14.4 million to 15 different political parties during the 2014 presidential and gubernatorial elections alone. ${ }^{19}$ João Vaccari, a former accountant of the PT party, claimed that he had received roughly US\$200 million for the PT party alone between 2003 and $2013 .{ }^{20}$ As evidenced by the previous investigations, the Petrobras bribery system paid out somewhere between US\$3 and 6 billion as political donations and bribes over the last 10-15 years.

So far, Operation Carwash investigators have shown that political corruption served various purposes in Brazil. It facilitated personal enrichment, funded election campaigns and political parties, and influenced legislations. The case of José Dirceu of the PT party, who was the former presidential minister and has been sentenced to more than 23 years in prison on charges of bribery, money laundering, and membership in a criminal organization, highlights the connections between personal enrichment and party interest. In one of these criminal trials, it became apparent that Petrobras's then-chairman of the board had bribed him to the tune of US\$ 3.9 million, part of which he then handed over to the PT party. However, he retained around US\$1 million for himself, which he then invested, for example, in real estate properties. ${ }^{21}$

Since the beginning of Operation Carwash, dozens of Brazilian politicians, members of government, and high-ranking officials, as well as top executives and entrepreneurs of many big companies, have been investigated. 193 inquiries, seven criminal processes against 100 people, and 212 agreements are currently going up in front of the Brazilian Supreme Court. Eight of President Michel Temer's 28 ministers have been investigated. Furthermore, twelve governors, 24 senators, and 39 deputies have been the target of investigations and legal proceedings in the Supreme Court and in the Electoral Tribunal. More than 200 politicians are involved in total. ${ }^{22}$ The Leniency Agreements and testimonies of implicated corporate managers and executives are shedding more and more light onto the dubious entanglements between politics and businesses in Brazil.

\section{The Political Actors: Political Leaders}

Brazil's corrupt political environment is neither associated with a single party, nor is grounded in particular family or social backgrounds. Politicians and members of the government who were investigated and arrested belong to different political

\footnotetext{
${ }^{19} \mathrm{http}: / /$ meucongressonacional.com/eleicoes2014/empresa/15102288000182

${ }^{20}$ See: criminal trials: 5045241-84.2015.4.04.7000, 5013405-59.2016.404.7000.

${ }^{21}$ Criminal Process 5,045241-84.2015.4.04.7000/PR.

${ }^{22} \mathrm{http}$ ///congressoemfoco.uol.com.br/noticias/sai-a-lista-de-fachin-ministro-do-stf-autorizainvestigacao-de-quase-100-politicos-na-lava-jato/
} 
parties and come from different interest groups, which in turn have different political goals and social conceptions. However, all seem to use similar practices to maintain their political positions and the primacy of their parties. As soon as a good relationship and a possible "money source" appears on the horizon, they snatch to bankroll their campaign and party, as well as to line their own pockets.

But politicians and their parties alone cannot maintain this politically deviant environment in Brazil. Big business also plays an important role here. However, it is difficult to say who is driving the system or who began it. Is it the political system that fails to show the company any way to be economically successful without corruption? Or are companies exploiting the political system's weakness in order to benefit themselves? In any case, it is the big companies that keep this system of corruption running. They not only have the necessary capital to fund the parties and politicians; they are also the ones who have the capacity to commit bribery and corruption schemes through government contracts. They are not only the means, but also the ends. As a quid pro quo, they received preferential treatment both in winning fat contracts and benefitting from legislative amendments for their enterprises.

The investigations of Operation Carwash make it clear that the arrests of, and harsh penalties given to, companies and politicians have not prevented them from continuing their corrupt practices. Once new detection measures are adopted, actors devise new strategies for fraud, bribery, and money laundering. Sooner or later, however, most of them land in an investigation. This is exactly the case of former Republic President Michel Temer, who was vehemently committed to impeaching the former President Dilma Rousseff. He is charged with corruption, money laundering, and the formation of a criminal organization. His "money source," the big Brazilian company J\&F Investimentos, which is currently being investigated in several corruption scandals, has reached an agreement with the public prosecution authority and has testified against almost all of his accomplices. ${ }^{23}$

Joesley Batista, the now resigned president of the J\&F Investimentos, presented the public prosecution authority with four pieces of what he claimed to be taped conservations with high-ranking politicians, including a conversation with former president Michel Temer. ${ }^{24}$ The recorded conversation clearly indicates that J\&F Investimentos was trying to prevent, with Temer's support, further investigations by the judiciary. To prevent Eduardo Cunha, the former President of the Chamber of Deputies, who has been arrested since October 2016, from testifying before the court, Joesley Batista takes care of the well-being and financial affairs of the Cunhas family. ${ }^{25}$ Batista also ensured that the testimonies from those currently in custody remained in tune with each other.

The Brazilian judiciary has, undoubtedly, been much more efficient in the investigation and prosecution of corruption cases in recent years. Not only have several regulative and institutional changes that have taken place over the last decades

\footnotetext{
${ }^{23}$ Testimony n. 7003.

${ }^{24}$ Inquiry n. 4483/STF.

${ }^{25}$ Inquiry n. 4489/STF.
} 
played a part, so have the Brazilians' changed perception and tolerance of corruption. However, many politicians in Brazil still seem to believe that in the end it will remain business-as-usual. The conviction of former President Luiz Inacio Lula da Silva (in July 2017, sentenced to nine-and-a-half years in jail by the Federal Court of Paraná $\left.{ }^{26}\right)$, the indictment against President Michel Temer, the investigations of eight state ministers, 24 senators, 39 members of the Chamber of Deputies, and eight governors, as well as the convictions and arrests of dozens of other politicians and top managers, do not seem to be enough to stop the hidden political corruption.

\section{A Case of Good Governance?}

Those who have hitherto been ignorant or have had no capacity to estimate the extent of political corruption are now being provided with more and more evidence by the Brazilian judiciary: A system of political corruption existed in Brazil, the extent of which is becoming increasingly evident with each additional legal proceeding. It is striking that none of Brazil's political leaders is willing to take the political responsibility. All are looking on and protesting their own innocence, until they are either taken to court or happily escape condemnation. This is also part of a political system which, as is now becoming more and more apparent, is characterized by organized irresponsibility and graft.

Joesley Batista and former president Michel Temer did not stop their conversation at the obstruction of justice, but showed clearly that the bribery system remains valid despite all the excitement and attention of the media, authorities, and the general populace. In this sense, the fear of being uncovered seemed to have been much lower than the fear of leaving the deeply institutionalized old corrupt patterns. Those transforming a political system characterized by corruption, such as Brazil's, must take time to consolidate the effect of institutional changes in its structure. Although policymakers have completed major regulative changes and institutional changes over the last decades, which have made an enormous difference in terms of improving transparency in public administration and strengthening press freedom and justice, they have not (yet) been able to eradicate systemic corruption. However, all these changes have contributed to the fact that the previous corruption scandals are now accessible online to all and well-publicized in the press. It is not enough to stop systemic corruption, but it is a first and important step in a long-term process. Further institutional changes on the political level are just as important. The introduction of new regulations and the law enforcement create a new possibility for changing attitudes in Brazilian business and politics, and they can also support the creation of new informal institutions, such as new expectations, beliefs, and perception, of ethics and good governance in Brazilian society. In that sense, our analysis has made clear that regulations alone cannot generate good governance attitudes,

${ }^{26}$ Criminal trial n. 5,046512-94.2016.4.04.7000/PR, sentence 948, July 12th, 2017. 
but require the institutionalization and legitimation of a new belief system, that should be shared in different groups such as business people, politicians, citizens, and organizations in a social and economic context. To conclude, the new era of law enforcement may be characterized as effective, with significant regulative and institutional changes. Law enforcement has been "good," shoving powerful interest groups aside. However, it remains unclear to what extent various interest groups and societal actors really engage in the fight against corruption. Parts of civil society have been influenced by the political parties and their interests. Most political parties are still in a state of shock and are not supporting the new era of law enforcement in Brazil If good governance is based on significant participation by various interest groups and societal actors in the fight against corruption, it is still missing in Brazilian society.

\section{References}

Article 33, Penal Code, § 4, Law Decree No. 2.848 [Art. 33 do Código Penal- Decreto Lei 2848/40 ]. (1940, December 7). Brazil. Retrieved from https://www.jusbrasil.com.br/topicos/10636569/ artigo-33-do-decreto-lei-n-2848-de-07-de-dezembro-de-1940

Barkemeyer, R., Preuss, L., \& Lee, L. (2015). Corporate reporting on corruption: An international comparison. Accounting Forum, 39, 349-365. https://doi.org/10.1016/j.accfor.2015.10.001

Bathelt, H., \& Glückler, J. (2014). Institutional change in economic geography. Progress in Human Geography, 38, 340-363. https://doi.org/10.1177/0309132513507823

Braithwaite, J. (2008). Regulatory capitalism: How it works, ideas for making it work better. Cheltenham: Edward Elgar.

Campbell, J.-L., \& Göritz, A. S. (2014). Culture corrupts! A qualitative study of organizational culture in corrupt organizations. Journal of Business Ethics, 120, 291-311. https://doi. org/10.1007/s10551-013-1665-7

Chaves, A. C. S. (2013). A corrupção privada no Brasil [Private corruption in Brazil]. Revista Jurídica ESMP-SP, 4, 231-260. https://doi.org/10.13140/2.1.2858.2084

Correia, I. D. (2015). Os principais aspectos da Lei Anticorrupção brasileira 12.846/2013 e a importância da cultura de compliance no ramo empresarial [The main aspects of the Brazilian Anti-Corruption Law 12.846/2013 and the importance of the compliance culture in the business sector]. Rio de Janeiro: Pontifícia Universidade Católica do Rio de Janeiro. https://doi. org/10.17771/PUCRio.acad.26080

Dallagnol, D. (2017). A luta contra a corrupção: A Lava Jato e o futuro de um país marcado pela impunidade [The fight against corruption: Lava Jato and the future of a country earmarked by impunity]. Rio de Janeiro: Primeira Pessoa.

Dantas de Araujo, F. (2012). Uma análise da Estratégia Nacional Contra a Corrupção e a Lavagem de Dinheiro (ENCCLA) por suas diretrizes [An analysis of the national strategy against corruption and money laundering (ENCCLA) by its directives]. Revista Brasileira de Políticas Públicas, 2(1), 53-82. https://doi.org/10.5102/rbpp.v2i1.1649

de Rugy, V., \& Warren, M. (2009). Expansion of regulatory budgets and staffing continues in the new administration: An analysis of the U.S. budget for fiscal years 2009 and 2010. Retrieved from https://www.mercatus.org/system/files/Regulators-Budget-Report-Final-VersionOctober-29.pdf

de Sanctis, F. M. (2015). Voice and accountability: Improving the delivery of anticorruption and anti-money laundering strategies in Brazil. In J. Wouters, A. Ninio, T. Doherty, \& H. Cisse' (Eds.), Improving delivery in development: The role of voice, social contract, and accountability 
(pp. 391-413). The World Bank Legal Review: Vol. 6. Washington, D.C.: World Bank Group. https://doi.org/10.1596/978-1-4648-0378-9

Filgueiras, F., \& Araújo, M. M. (2014). A política anticorrupção e o marco legal no Brasil [Anticorruption policy and the legal landmark in Brazil]. In I. F. Cunha \& E. Serrano (Eds.), Cobertura jornalística da corrupção política: Sistemas políticos, sistemas mediáticos e enquadramentos legais (pp. 36-71). Lisboa: Alêtheia Editores.

Glückler, J., \& Lenz, R. (2016). How institutions moderate the effectiveness of regional policy: A framework and research agenda. Investigaciones Regionales, 36, 255-277.

Glückler, J., Suddaby, R., \& Lenz, R. (2018). On the spatiality of institutions and knowledge. In J. Glückler, R. Suddaby, \& R. Lenz (Eds.), Knowledge and institutions (pp. 7-40). Knowledge and Space: Vol. 13. Cham: Springer. https://doi.org/10.1007/978-3-319-75328-7

Jordana, J., Levi-Faur, D., \& Fernández i Marín, X. (2011). The global diffusion of regulatory agencies: Channels of transfer and stages of diffusion. Comparative Political Studies, 44, 1343-1369. https://doi.org/10.1177/0010414011407466

Lei Complementar No. 101 [Tax Liability Law No. 101]. (2000, May 4). Brazil. Retrieved from http://www.planalto.gov.br/ccivil_03/leis/lcp/lcp101.htm

Lei Complementar No. 131 [Tax Liability Law No. 131]. (2009, May 27). Brazil. Retrieved from http://www.planalto.gov.br/ccivil_03/leis/lcp/lcp131.htm

Lei No. 8.112 [Law No. 8.112]. (1990, December 11). Brazil. Retrieved from http://www.planalto. gov.br/ccivil_03/leis/18112cons.htm

Lei No. 8.429 [Law of Administrative Improbity No. 8.429]. (1992, June 2). Brazil. Retrieved from http://www.planalto.gov.br/ccivil_03/leis/18429.htm

Lei No. 8.666 [Bidding Law No. 8.666]. (1993, June 21). Brazil. Retrieved from http://www.planalto.gov.br/ccivil_03/leis/18666cons.htm

Lei No. 9.613 [Law of Money Laundering No. 9.613]. (1998, March 3). Brazil. Retrieved from http://www.planalto.gov.br/ccivil_03/Leis/L9613compilado.htm

Lei No. 10.520 [Bidding Law No. 10.520]. (2002, July 17). Brazil. Retrieved from http://www. planalto.gov.br/ccivil_03/LEIS/2002/L10520.htm

Lei No. 12.527 [Freedom of Information Act, Law No. 12.527]. (2011, November 18). Brazil. Retrieved from http://www.planalto.gov.br/ccivil_03/_ato2011-2014/2011/lei/112527.htm

Lei No. 12.846 [Anti-Corruption Act, Law No. 12.846]. (2013, August 1). Brazil. Retrieved from http://www.planalto.gov.br/ccivil_03/_Ato2011-2014/2013/Lei/L12846.htm

Lei No. 12.850 [Law of Criminal Organizations No. 12.850]. (2013, August 2). Brazil. Retrieved from http://www.planalto.gov.br/ccivil_03/_Ato2011-2014/2013/Lei/L12850.htm

Netto, V. (2016). Lava Jato: O juiz Sergio Moro e os bastidores da operação que abalou o Brasil [Lava Jato: Judge Sergio Moro and the backstage of the operation that shook Brazil]. Rio de Janeiro: Sextante.

Pascolati Junior, U. A. (2016). Corrupção privada do direito brasileiro [Private corruption in the Brazilian Law]. In A. J. C. da Cunha Filho, G. R. B. de Araújo, R. Livianu, \& U. A. Pascolati Junior (Eds.), 48 Visões sobre a corrupção (pp. 147-163). São Paulo: Quartier Latin.

Passas, N., \& Kleinhempel, M. (2016). Transparency and compliance policies of multinational companies in Latin America. In A. Stachowicz-Stanusch (Ed.), Corporate social performance in the age of irresponsibility: Cross national perspective (pp. 79-88). Contemporary Perspectives in Corporate Social Performance and Policy: Vol. 21. Charlotte: Information Age.

Petrobras. (2014). Comissão Interna de Apuração: Protocolo de Registro na Segurança Empresarial n. ${ }^{\circ}$ 31/2014 [Internal Investigation Commission: Protocol for Registration in Business Security] (DIP DABAST 71/2014). Retrieved from https://politica.estadao.com.br/blogs/ fausto-macedo/wp-content/uploads/sites/41/2018/01/3_COMP115.pdf

Pizarro, L. (2015, July 11). Programas anticorrupção no Brasil são 'para inglês ver' [Anticorruption programs in Brazil are 'for the English to see']. O TEMPO (Contagem). Retrieved from http://www.otempo.com.br/capa/economia/programas-anticorrup\%C3\%A7\%C3\%A3ono-brasil-s\%C3\%A3o-para-ing1\%C3\%AAs-ver-1.1068058 
Richard, M. (2014). Brazil's landmark anti-corruption law. Law and Business Review of the Americas, 20, 141-148. Retrieved from https://scholar.smu.edu/lbra/vol20/iss 1/9/

Scott, W. R. (2014). Institutions and organizations: Ideas, interests, and identities (4th ed.). Los Angeles: SAGE.

Wohlnick, A., \& Correia, I. D. (2016). Korruptionsbekämpfung und Compliance in Brasilien: Das Antikorruptionsgesetz 12.846/2013 und seine Bedeutung für in Brasilien tätige Unternehmen [Anti-corruption and compliance in Brazil: The Anti-Corruption Law 12.846/2013 and its significance for companies operating in Brazil]. Zeitschrift für Internationales Wirtschaftsrecht (IWRZ), 5, 210-214.

Open Access This chapter is licensed under the terms of the Creative Commons Attribution 4.0 International License (http://creativecommons.org/licenses/by/4.0/), which permits use, sharing, adaptation, distribution and reproduction in any medium or format, as long as you give appropriate credit to the original author(s) and the source, provide a link to the Creative Commons license and indicate if changes were made.

The images or other third party material in this chapter are included in the chapter's Creative Commons license, unless indicated otherwise in a credit line to the material. If material is not included in the chapter's Creative Commons license and your intended use is not permitted by statutory regulation or exceeds the permitted use, you will need to obtain permission directly from the copyright holder. 